\title{
Genetic polymorphism among natural populations of Anacardium humile A. ST-HIL
}

\author{
Silvia Correa Santos ${ }^{1}$, Raquel dos Santos Carvalho², \\ Livia Maria Chamma Davide ${ }^{1}$
}

\begin{abstract}
The genus Anacardium presents nine species, of these, three have sub-bush size, common in the Cerrado of the Center-West of Brazil. The objective of this work was to evaluate the genetic variability of the species, collected in eleven provenances, using RAPD markers. Genomic DNA from 122 accessions was extracted and amplified with 25 decamer primers. The results indicated polymorphism, ranging from $77.71 \%$ to $96.18 \%$. The distribution of genetic diversity among and within populations shows that $27.14 \%$ of the variability is found between populations and $37.44 \%$ within the populations, suggesting the existence of genetic variability that may be related to the reproductive strategies adopted by the species throughout its evolution. The index of variation within the provenances $(93.36 \%)$ was higher than the index found among populations (6.64\%). Molecular analysis indicated that there is genetic divergence between and within the studied populations of Anacardium humile A. St. - Hill. The origin of Itajá-GO presented the highest genetic diversity, presenting the highest values of genetic diversity index, phenotypic diversity and higher percentage of polymorphic loci.
\end{abstract}

Index terms: genetic variability, diversity, native species, Cerrado.

\section{Polimorfismo genético entre populações naturais de Anacardium humile A. ST-HIL}

\section{Corresponding author: silviasantos@ufgd.edu.br \\ Received: April 02, 2019 Accepted: October 07, 2019}

Copyright: All the contents of this journal, except where otherwise noted, is licensed under a Creative Commons Attribution License.

\section{(cc) $\mathbf{E Y}$}

\begin{abstract}
Resumo - O gênero Anacardium apresenta nove espécies, das quais, três possuem porte subarbustivo, comuns no Cerrado do Centro-Oeste Brasileiro (A. humile, A. nanum e A. corymbosum). Nos últimos anos, com a expansão da agricultura, observa-se diminuição das áreas de ocorrência, e além disso encontram-se poucos trabalhos visando à domesticação da espécie. O objetivo deste trabalho foi avaliar a variabilidade genética da espécie, coletadas em onze procedências, utilizando marcadores RAPD. O DNA genômico de 122 acessos foi extraído e amplificado com 25 iniciadores decâmeros. Os resultados indicaram polimorfismo, que variou de $77,71 \%$ a $96,18 \%$. A distribuição da diversidade genética entre e dentro das populações demonstra que $27,14 \%$ da variabilidade encontram-se entre populações e $37,44 \%$ dentro das populações, sugerindo a existência de variabilidade genética que pode estar relacionada às estratégias reprodutivas adotadas pela espécie ao longo de sua evolução. O índice de variação dentro das procedências $(93,36 \%)$ foi superior ao índice encontrado entre populações $(6,64 \%)$. A análise molecular indicou que há divergência genética entre e dentro das populações estudadas de Anacardium humile A. St. Hill. A origem de Itajá-GO, apresentou a maior diversidade genética, apresentando os maiores valores de índice de diversidade genética, diversidade fenotípica e maior porcentagem de locos polimórficos.
\end{abstract}

Termos para indexação: variabilidade genética, diversidade, espécies nativas, Cerrado. 
In Brazil, the genus Anacardium presents nine species, and of these, three are sub-shrub, common in Cerrado areas of the Brazilian Center-West (A. humile, $A$. nanum and $A$. corymbosum) (SILVA-LUZ and PIRANI, 2010). O Anacardium humile is popularly known as cajuzinho-do-cerrado or cajuí, and stands out due to the exotic flavor of its false fruit, presenting medicinal and alimentary potential, being able to be included in the group of tropical fruit trees and antioxidant (ROCHA et al. 2013).The species occurs frequently in a dirty field and Cerrado stricto sensu (SILVA-LUZ and PIRANI, 2010); RESSEL et al., 2015).

The cajuzinho-do-cerrado presents high genetic divergence, ranging from the size to the fruit (Brown and Wier, 1983). Studies aiming at the knowledge of genetic variability, seeking to identify provenances and/ or environments that have accesses with high genetic divergence may generate information for future work on their commercial potential.

According to Lacerda and Kageyama (2003), the establishment of strategies for genetic conservation of a species includes the study of the distribution of genetic variability among and within their populations.

To assist in the characterization of genetic variations of populations there are molecular techniques, which associated with statistical analyzes can provide important information, such as genetic similarity and dissimilarity. Among these, the molecular markers that provide a more specific approach to each individual and are much more efficient for the determination of genetic variability, by directly analyzing the genetic material, when compared to the use of the morphological characteristics (YANAKA et al., 2005).

In recent studies on fruit species and have generated interesting results with: cagaita, fava d'anta (OLIVEIRA, 2008), pitayas (JUNQUEIRA et al., 2010), and coconut (RAJESH et al., 2014). Knowledge of the genetic parameters of a species assists in the targeting of breeding, management and genetic conservation programs.

Considering the importance of knowing the genetic diversity of this fruit tree of the Cerrado biome, the present study evaluated the genetic variability of the species Anacardium humile A. ST-HIL. in eleven provenances.

Newly mature leaves were collected from 122 accessions from 10 sources from the state of Goiás (Aporé, Caiapônia, Chapadão do Céu, Doverlândia, Itajá, Itarumã, Jataí, Mineiros, Santo Antônio do Descoberto and Serranópolis) and 01 from the state of Mato Grosso (Barra do Garça), Brazil (Table 1). The leaves were stored in freezer $\left(-20^{\circ} \mathrm{C}\right)$ for better preservation. The genomic DNA was extracted using the protocol of Faleiro et al. (2003), with modifications in the concentration of betamercaptanol, with 10 times more and with the time of immersion in water bath reduced to half. After extraction, the total DNA of each plant was quantified by spectrophotometry. Then the stock solution of the DNA was diluted to the final working concentration of approximately $5 \mathrm{ng} \mu \mathrm{L}^{-1}$.

The amplifications were done in a thermal cycler programmed according to Barros et. al. (2005), for 40 cycles, each consisting of the following sequence: 15 seconds at $94^{\circ} \mathrm{C}, 30$ seconds at $35^{\circ} \mathrm{C}$ and 90 seconds at $72^{\circ} \mathrm{C}$. After completion of the 40 cycles, a six minute extension step was performed at $72^{\circ} \mathrm{C}$ and reduction to $4^{\circ} \mathrm{C}$. After the PCR reaction, $3 \mu \mathrm{L}$ of the mixture of bromophenol blue $(0.25 \% \mathrm{w} / \mathrm{v})$, glycerol $(60 \% \mathrm{v} / \mathrm{v})$ in water was added to each sample (with the purpose of assisting the visualization of the Progress of the DNA race in electrophoresis). The total volume of each sample was applied on agarose gel (1.2\%), stained with ethidium bromide, submerged in TBE buffer $(90 \mathrm{mM}$ Tris-Borate, 1 mM EDTA, and ethidium bromide). The electrophoretic separation was carried out for 3 hours at 90 volts. At the end of each electrophoresis, the gels were photographed under ultraviolet light.

The generated RAPD markers were converted into a binary data matrix, from which the genetic distances between the 122 accessions were estimated based on the complement of the Nei e Li similarity coefficient (NEI e LI, 1979). The genetic distance matrix was used for cluster analysis by the Tocher method, and with the help of the GENES program (CRUZ, 2008).

The characterization of the genetic variability was done with the help of the Popgene software (Young et al. 2000), being carried out the analysis between and inside provenances of cajuzinho-do-cerrado. The number of alleles observed (n), number of effective alleles (ne), Shannon index (Ĥ0), Nei (1973) gene diversity (Ĥe) and percentage of polymorphic loci $(\mathrm{P} 95 \%=$ number $\mathrm{Of}$ polymorphic loci / total number of loci). For the P95\% values, a $95 \%$ probability criterion was adopted where a locus is considered polymorphic if the frequency of the most common allele did not exceed 95\% (MARTINSCORDER et al., 2009). The total heterozygosity $(\mathrm{Ht})$, mean heterozygosity within (Hs), population differentiation coefficient (Gst) and allelic flux (Nm) were also estimated (OLIVEIRA et al., 2008).

Genetic variability between and within populations was estimated using the GENES program (Cruz, 2008) using the genetic variance analysis (AMOVA). The AMOVA calculates the value Fst, which according to Excoffier et al. (1992) equals the proportion of the total genetic variation fractional among the provenances. Of the 25 primers (Table 2), 10 were selected for characterization of the genetic polymorphism between and within the provenances under study. A total of 146 bands with a mean of 14.6 bands per primer were obtained. The values estimated in this study (Table 2) ranged from 0.4135 to 0.5497 , indicating that the provenances present moderate to low diversity. 
Table 1. Accesses, provenances, and georeferenced data (DG) of the 122 accessions of Anacardium humile A. STHIL.

\begin{tabular}{|c|c|c|}
\hline ACCESSES & PROVENANCES & DG \\
\hline $01,02,03,04,05,06,07,08,09$ e 10 (10 accesses); & Mineiros-GO & $\begin{array}{l}\text { Altitude: } 704 \mathrm{~m} \\
\text { S: } 17 \cdot 0,66 \cdot 0,130 \\
\text { W: } 52 \cdot 0,5 \cdot 0,271\end{array}$ \\
\hline $\begin{array}{l}11,12,13,14,15,16,17,18,19,20,21,22,23,24 \text { e } 25 \\
\text { (15 accesses); }\end{array}$ & Barra da Garça-MT & $\begin{array}{l}\text { Altitude: } 570 \mathrm{~m} \\
\text { S: } 15 \cdot 0,85 \cdot 0,072 \\
\text { W: } 52 \cdot 0,25 \cdot 0,048\end{array}$ \\
\hline $\begin{array}{l}26,27,28,29,30,31,32,33,34,35,36,37,38,39 \text { e } 40 \\
(15 \text { accesses); }\end{array}$ & Doverlândia-GO & $\begin{array}{l}\text { Altitude: } 618 \mathrm{~m} \\
\text { S: } 16.0,71.0,09 \\
\text { W: } 52.0,15.0,0125\end{array}$ \\
\hline $41,42,43,44,45,46,47,48,49$ e 50 (10 accesses); & Itarumã-GO & $\begin{array}{l}\text { Altitude: } 637 \mathrm{~m} \\
\text { S: } 18 \cdot 0,6 \cdot 0,0272 \\
\text { W: } 51 \cdot 0,76.0,093\end{array}$ \\
\hline $51,52,53,54,55,56,57,58$ e 59 (10 accesses); & Itajá-GO & $\begin{array}{l}\text { Altitude: } 484 \mathrm{~m} \\
\text { S: } 18 \cdot 0,85 \cdot 0,225 \\
\text { W: } 51 \cdot 0,53 \cdot 0,228 \\
\end{array}$ \\
\hline $60,61,62,63,64,65,66,67,68$ e 70 (10 accesses); & Chapadão do Céu-GO & $\begin{array}{l}\text { Altitude: } 809 \mathrm{~m} \\
\text { S: } 18 \cdot 0,216.0,112 \\
\text { W: } 52.0,86.0,165\end{array}$ \\
\hline $71,72,73,74,75,76,77,78$ e 79 (09 accesses); & Aporé-GO & $\begin{array}{l}\text { Altitude: } 681 \mathrm{~m} \\
\text { S: } 18 \cdot 0,783 \cdot 0,147 \\
\text { W: } 52 \cdot 0,08 \cdot 0,182 \\
\end{array}$ \\
\hline $80,81 \mathrm{a}, 81 \mathrm{~b}, 82,83,84,85,86,87,88,89$ (11 acessos); & Serranópolis-GO & $\begin{array}{l}\text { Altitude: } 577 \mathrm{~m} \\
\text { S: } 18 \cdot 0,35 \cdot 0,147 \\
\text { W: } 52 \cdot 0,93 \cdot 0,075\end{array}$ \\
\hline $91,92,93,94,95,96,97,98,99$ e 100 (10 accesses); & Jataí-GO & $\begin{array}{l}\text { Altitude: } 708 \mathrm{~m} \\
\text { S: } 17 \cdot 0,90 \cdot 0,0163 \\
\text { W: } 51 \cdot 0,68 \cdot 0,256\end{array}$ \\
\hline $\begin{array}{l}\begin{array}{l}101,102,103,104,105,107,108,109 \text { e } 110(09 \\
\text { accesses); }\end{array}\end{array}$ & Caiapônia-GO & $\begin{array}{l}\text { Altitude: } 599 \mathrm{~m} \\
\text { S: } 16.0,7.0,0165 \\
\text { W: } 52.0,11.0,0066\end{array}$ \\
\hline $\begin{array}{l}\text { 111, } 112,113,114,115,116,117,118,119,120,121, \\
122,123 \text { e } 124 \\
\text { (14 accesses); }\end{array}$ & $\begin{array}{l}\text { Santo Antônio do } \\
\text { Descoberto-GO }\end{array}$ & $\begin{array}{l}\text { Altitude: } 1050 \mathrm{~m} \\
\text { S: } 15 \cdot 0,98 \cdot 0,00438 \\
\text { W: } 48 \cdot 0,21 \cdot 0,0150\end{array}$ \\
\hline
\end{tabular}


Table 2. Number of total bands, number of polymorphic bands, percentage of polymorphism, average of bands per primers, expressive primers, less expressive primers, bootstrap and measure of heterogeneity between bands, using RAPD marker in the cajuzinho-do-cerrado, by provenances collection.

\begin{tabular}{lllllllll}
\hline PROVENANCES & Ntb**** & Npb & \%P & Abp & EP & LEP & BStrap & B \\
\hline Aporé-GO* & 154 & 140 & 91 & 14 & OPA11 e OPA08 & OPM03 & 65 & 0,48 \\
Barra do Garça-MT* & 155 & 146 & 94 & 14,6 & OPA11 & OPA04 & 50 & 0,47 \\
Caiapônia-GO* & 136 & 132 & 97 & 13,2 & OPA08 e OPA09 & OPA04 & 45 & 0,46 \\
Chapadão do Céu-GO* & 155 & 144 & 93 & 14,4 & OPA11 & OPA04 & 70 & 0,47 \\
Santo Antonio do Descoberto-GO* & 148 & 146 & 99 & 14,6 & OPA11 & OPM03 & 140 & 0,43 \\
Doverlândia-GO* & 156 & 146 & 93 & 14,6 & OPA11 & OPA04 & 40 & 0,47 \\
Itajá-GO* & 153 & 141 & 92 & 14,1 & OPA11 e OPA08 & OPB05 & 70 & 0,47 \\
Itarumã-GO* & 153 & 143 & 93 & 14,3 & OPA- 11 & OPA04 & 130 & 0,43 \\
Jataí-GO* & 138 & 115 & 83 & 11,5 & OPM02 & OPA04 & 35 & 0,48 \\
Mineiros-GO* & 156 & 141 & 90 & 14,1 & OPA08 & OPM03 & 58 & 0,48 \\
Serranópolis-GO* & 153 & 148 & 97 & 14,8 & OPA11 & OPA04 & 118 & 0,45 \\
\hline Municípios** & 146 & 134 & 92 & 13,4 & OPA11 e OPA08 & OPN05 & 85 & 0,46 \\
\hline All accesses*** & 157 & 156 & 99 & 15,6 & OPA11 & OPA18 & 90 & 0,37 \\
\hline
\end{tabular}

* Analysis performed with access within each municipality; ** analysis performed among municipalities; *** analysis performed with all 122 accesses; $* * * *$ $\mathrm{Ntb}=$ number of total bands; $\mathrm{Npb}=$ number of polymorphic bands; $\% \mathrm{P}=$ percentage of polymorphism (or polymorphism rate); EP = expressive primers; LEP $=$ less expressive primers; $\mathrm{Abp}=$ Average bands per primers, BStrap $=$ bootstrap and $\mathrm{b}=$ measure of heterogeneity between bands.

The percentage of polymorphic loci (P 95\%) (Table 3) varied from $77.71 \%$ in the Jataí origin to $96.18 \%$ in the Itaja source. It can be noted that only the origin of Jataí and Caiapônia did not present P95\% higher than $90 \%$. The distribution of the genetic diversity of $\mathrm{Nei}(\hat{\mathrm{He}})$ between and within the provenances (Table3) ranged from 0.2714 (source of Caiapônia) to 0.3744 (source of Itajá). The Shannon index (Ĥ) is estimated from the presence frequencies and band absences. The total genetic heterozygosity (HT) obtained can be considered to be relatively high (Table 4), presenting a small deviation, indicating value very close to the mean $(0.3821 \pm 0.0115)$ for most loci.The GST value found in this study among the provenances was 0.1167 (Table 4), indicating that $11.67 \%$ of the genetic divergence is between provenances and $88.33 \%$ within provenances.

The results of the analysis of molecular variance - AMOVA (Table 5) show the variation index within and among the populations of Anacardium humile. The index of variation within the provenances $(93.36 \%)$ was higher than the index found among populations (6.64\%), which although low, was highly significant. The results are in agreement with the expected ones in cerrado woody species, that is, considerable levels of genetic variability exist within their populations and with high levels of divergence. The Fst value (0.0664) observed (Table 6) shows moderate genetic differentiation.

In the cluster analysis between the 122 accessions of cajuzinho-do-cerrado, from the dissimilarity index of Nei e Li and the criterion of Tocher grouping (Table 6), five groups were obtained, four of which are constituted by only one access and a group with the other accesses.

Knowledge of the degree of genetic variability, through divergence studies, is fundamental in the process of identifying new sources of genes of interest. One of the ways to evaluate diversity is molecular characterization, which allows, from genetic marks, indifferent to environmental interference, to infer about the degree of diversity between individuals and between populations.

In the work of Gomes Filho et al. (2010), the RAPD markers were effective in investigating the diversity among guava tree accesses, indicating that the studied population has a wide genetic variability. This result is indicative of the lower genetic variability in these origins. For the others, the percentage of polymorphic loci (P95\%) was close to the values found by Zimback et al. (2004). The number of alleles observed (na) varied from 1.7771 to 1.9618, while the number of effective alleles (ne) ranged from 1.4511 to 1.6615 among provenances.

The values of $(\hat{\mathrm{He}})$ found in this study can be considered superior to those found by Oliveira et al. (2008) and close to those of Zimback et al. (2004). Despite being a species with populations threatened by intensive agriculture, landscape fragmentation and extractivism, there is genetic variability, probably due to the reproductive strategies adopted by the species throughout its evolution. However, studies with reproduction biology of $A$. humile should be carried out in order to better understand the reproductive strategies, which allow for new genotypic combinations in the offspring.

The provenance that presented the greatest diversity among all the studied origins was that of Itajá. This 
result was superior to that found in other species, which used similar methodologies (TOREZAN et al., 2005; OLIVEIRA et al., 2008).

Genetic heterozygosity is defined by Brown e Weir (1983) as being the most important measure to estimate genetic variability, which is less influenced by variations in sample size when compared to other variables. Which according to Zimback et al (2004), is indicative that the species presents a reasonable reserve of genetic variability. Similar values of HT were found by Zimbacka et al (2004) and Oliveira et al. (2008).

Genetic divergence (GST) is a statistical data that measures the genetic differentiation between populations, and has been widely used since it is not affected by the reproductive system of the species, by the number of alleles per locus and by the evolutionary action (Moura, 2005). Their values vary from 0 to 1 , and according to Yeh (2000) values lower than 0.050 indicate low levels of genetic differentiation, in contrast values above 0.151 , are an indication of great genetic differentiation This result is lower than that reported in the literature for other tropical allogamous species, which presented GST values of $0.125,0.270,0.281$ and 0.285 , respectively: Zimback et al. (2004), Wadt (2001) and Sales et al. (2001).

The value of the gene flow $(\mathrm{Nm})$ observed was 3.78 , which is considered moderate according to Wrigth (1931), who stated that values of gene flow less than 1 indicate genetic isolation. This same author states that gene flow value greater than 1 is sufficient to prevent random losses of alleles within populations (drift effects). According to Wright (1978), which indicates this classification to values between 0.05 and 0.15 . However, it can be inferred that the Fst value was not higher, due to the possible occurrence of pollination of pollen accesses of genetically close individuals (FRANZON et al., 2010).

In the cluster analysis between the 122 accessions of cajuzinho-do-cerrado, from the dissimilarity index of Nei and Li and the criterion of Tocher grouping, five groups were obtained, four of which are constituted by only one access And a group with the other accesses. This structure of grouping of accesses confirms the result of the analysis, which showed a greater genetic divergence within the provenances than among provenances, due to the fact that there was no formation of groups with accesses distributed by source. This result is similar to those obtained by Oliveira et al. (2008) and Franzon et al. (2010).

The accessions from Itajá origin were distributed in $60 \%$ of the groups formed, this can be justified because this provenance presented the highest values for the percentage of polymorphic loci (P 95\%), for genetic diversity of Nei $(\hat{H e})$ and for the index Of Shannom of phenotypic diversity (H0), showing the provenance presents diversity and alleles that should be better studied. Molecular analysis indicated that there is genetic divergence between and within the studied populations of Anacardium humile A. St. - Hill (Figure 1). The origin of Itajá-GO presented the highest genetic diversity, presenting the highest values of genetic diversity index, phenotypic diversity and higher percentage of polymorphic loci.

Table 3. Genetic diversity of natural populations of Anacardium humile A. St.-Hil.

\begin{tabular}{lccccc}
\hline Prov* & $\mathbf{P}$ & \multicolumn{1}{c}{ na** } & ne** & $\hat{\mathrm{H}}_{\mathrm{e}}^{* *}$ & $\hat{\mathrm{H}}_{0}^{* *}$ \\
\hline AP & 90,45 & $1,9045(0,2949)$ & $1,5847(0,3300)$ & $0,3365(0,1598)$ & $0,4979(0,213)$ \\
BG & 92,99 & $1,9299(0,2561)$ & $1,6469(0,3114)$ & $0,3658(0,1467)$ & $0,5353(0,1939)$ \\
C & 84,08 & $1,8408(0,3671)$ & $1,4511(0,3394)$ & $0,2714(0,1726)$ & $0,4135(0,2356)$ \\
CC & 92,36 & $1,9236(0,2665)$ & $1,5857(0,3187)$ & $0,3400(0,1501)$ & $0,5052(0,1973)$ \\
D & 91,08 & $1,9108(0,2859)$ & $1,6615(0,316)$ & $0,3701(0,1509)$ & $0,5384(0,2022)$ \\
Itj & 96,18 & $1,9618(0,1923)$ & $1,6579(0,2859)$ & $0,3747(0,1314)$ & $0,5497(0,1687)$ \\
Ita & 93,63 & $1,9363(0,245)$ & $1,5656(0,329)$ & $0,3299(0,1529)$ & $0,4937(0,1977)$ \\
J & 77,71 & $1,7771(0,4175)$ & $1,5431(0,3827)$ & $0,3046(0,1947)$ & $0,4452(0,2696)$ \\
M & 91,08 & $1,9108(0,2859)$ & $1,6067(0,3256)$ & $0,3468(0,1558)$ & $0,5111(0,207)$ \\
SAD & 92,99 & $1,9299(0,2561)$ & $1,5183(0,2952)$ & $0,3147(0,1412)$ & $0,4776(0,1862)$ \\
S & 95,54 & $1,9554(0,2071)$ & $1,6192(0,2977)$ & $0,3581(0,1358)$ & $0,5301(0,1741)$ \\
\hline Total & 100 & $2(0)$ & $1,6674(0,2573)$ & $0,3842(0,1065)$ & $0,5662(0,1245)$
\end{tabular}

* Prov. = Provenance: Aporé (Ap), Barra do Garça (BG), Caiapônia (C), Chapadão do Céu (CC), Doverlândia (D), Itajá (Itj), Itarumã (Ita), Jataí (J), Mineiros (M), Santo Antônio do Descoberto (SAD), Serranópolis (S). (): standard deviation; P: percentage of polymorphic loci; Na **: number of alleles observed; Ne **: number of effective alleles; $\hat{\mathrm{He}}$ **: genetic diversity of Nei; $\hat{\mathrm{H}} 0 * *$ : Shannon index of phenotypic diversity. 
Table 4. Population genetic parameters of Anacardium humile A. St.-Hill.

\begin{tabular}{lllll}
\hline & $\mathbf{H}_{\mathrm{T}}$ & $\mathbf{H}_{\mathrm{S}}$ & $\mathbf{G}_{\mathrm{ST}}$ & $\mathbf{N m}^{*}$ \\
\hline Average & 0,3821 & 0,3375 & 0,1167 & 3,7852 \\
Standard deviation & 0,0115 & 0,0093 & & \\
\hline HT: total heterozygosity; HS: mean genetic diversity within; GST: gene divergence among populations; and Nm: gene flow.
\end{tabular}

Table 5. Molecular variance analysis (AMOVA) of populations of A. humile A. St.-Hill.

\begin{tabular}{llllll}
\hline SV & DF & SS & MS & Porcentage & P \\
\hline Entre & 10 & 498.9744 & 49,8974 & 6.639 & $<0,001$ \\
Dentro & 121 & 3101.0082 & 27,9372 & 93.360 & $<0,001$ \\
\hline Total & 131 & 3600.0082 & 29,7521 & & \\
\hline
\end{tabular}

$\mathrm{F}_{\mathrm{st}} \quad 0,0664 * *$

* SV = source of variation; DF = degree of freedom; SS = sum of squares; MS = middle-square; Fst = proportion of fractional total genetic variation among populations; ** significant at the $1 \%$ probability of error level.

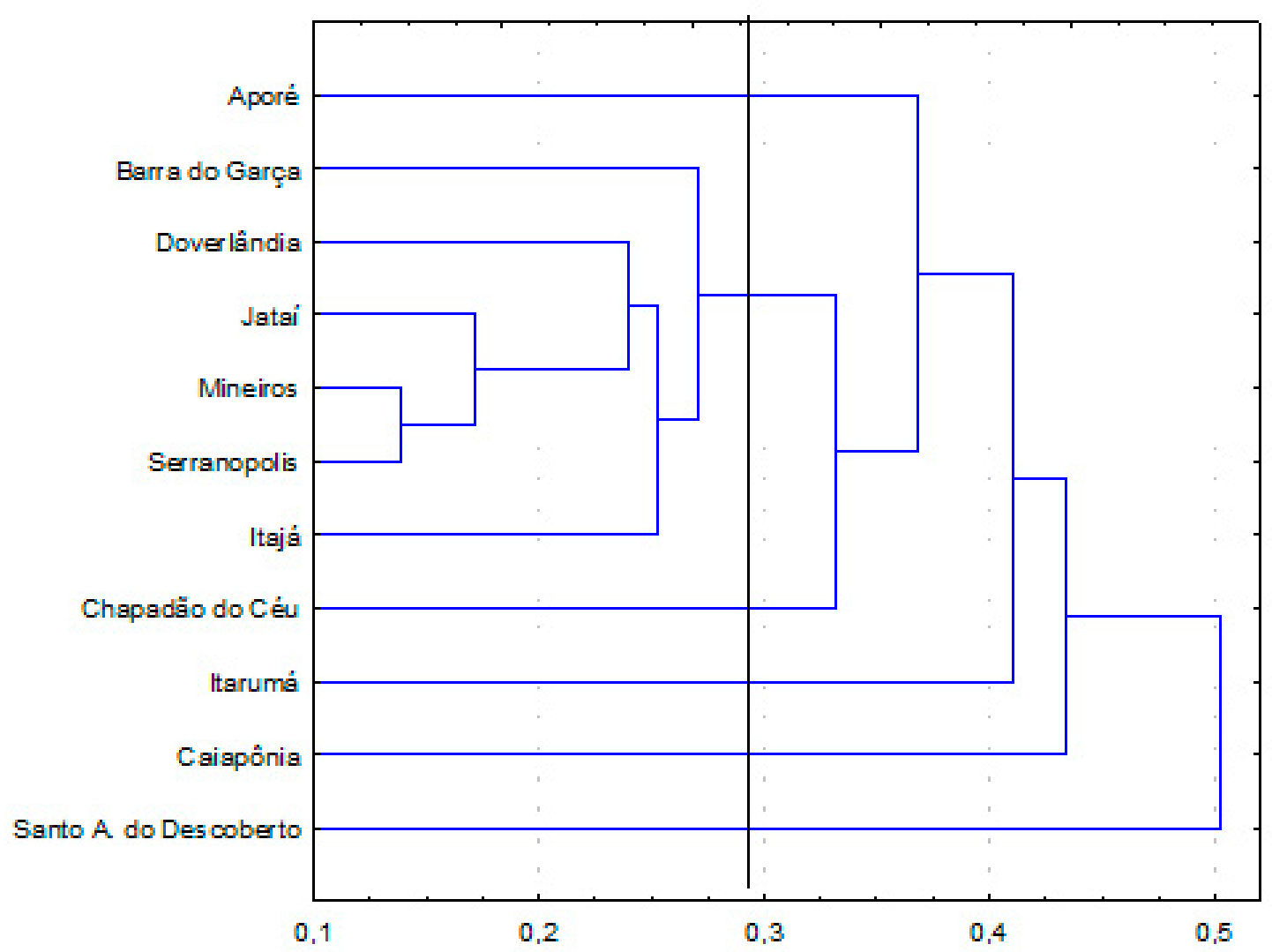

Figura 1. Dendrogram of genetic dissimilarities, from RAPD, among 11 provenances of Cajuzinho-doCerrado obtained by UPGMA method based on DNA marker matrix $(\mathrm{dg}=0.37)$. 
Table 6. Grouping by the Tocher method between accesses of $A$. humile A. St.-Hill. based on the distance matrix generated from molecular data analysis.

\begin{tabular}{|c|c|}
\hline Group & Accesses \\
\hline I & 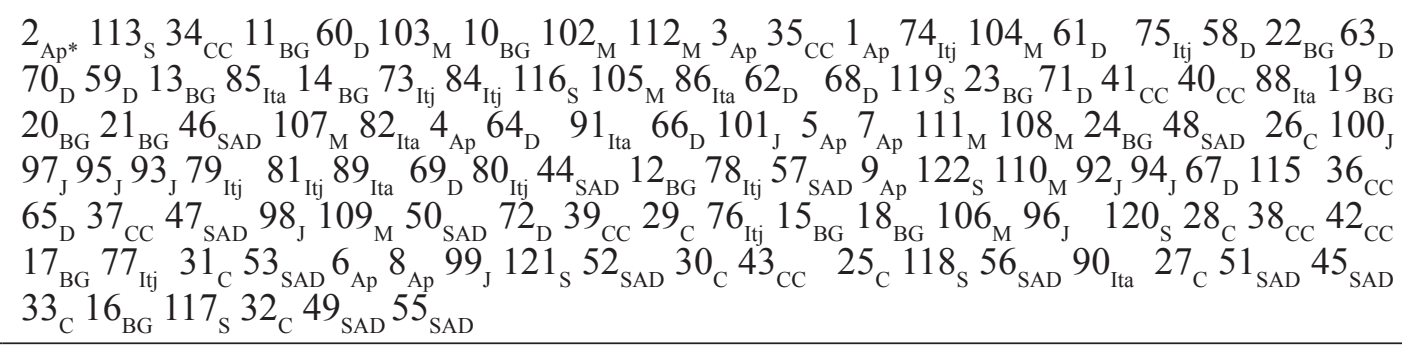 \\
\hline II & $114_{\mathrm{s}}$ \\
\hline III & $87_{\text {Ita }}$ \\
\hline IV & $83_{\text {Ita }}$ \\
\hline $\mathbf{V}$ & $54_{\mathrm{SAD}}$ \\
\hline
\end{tabular}

*Provenance: Aporé (Ap), Barra do Garça (BG), Caiapônia (C), Chapadão do Céu (CC), Doverlândia (D), Itajá (Itj), Itarumã (Ita), Jataí (J), Mineiros (M), Santo Antônio do Descoberto (SAD), Serranópolis (S).

\section{Acknowledgment}

To the CNPq for the financial support (Project Casadinho UFG and UFV-CNPq).

\section{References}

BARROS, A.M.; FALEIRO, F.B.; KARIA, C.T.; SHIRATSUCHI, LS.; ANDRADE, R.P.; LOPES, G.B. Variabilidade genética e ecológica de Stylosanthes macrocephala determinadas por RAPD e SIG. Pesquisa Agropecuária Brasileira, Brasília, DF, v.40, p.899-09, 2005.

BROWN, A. H. D.; WEIR, B.S. Measuring genetic variability in plant populations. Developments in Plant Geneticis and Breeding, v.1, p.219-239, 1983. In: CARVALHO, M.P. et al. Emergência de plântulas de Anacardium humile A. St.-Hil. (Anacardiaceae) avaliada por meio de amostras pequenas. Revista Brasileira de Botânica, São Paulo, v.28, p.627-33. 2005.

CRUZ, C.D. Programa genes: diversidade genética. Viçosa: Editora UFV, 2008. v.1, 278p.

EXCOFFIER, L.; SMOUSE, P.E.; QUATTRO, J.M. Analysis of molecular variance inferred from metric distances among DNA haplotypes - application to human mitochondrial-DNA restriction data. Genetics, Austin, v.131, p.479-91, 1992.
FALEIRO, F.G.; FALEIRO, A.S.G.; CORDEIRO, M.C.R.; KARIA, C.T. Metodologia para operacionalizar a extração de DNA de espécies nativas do cerrado visando a análises moleculares. Planaltina: Embrapa Cerrados, 2003. 5p. (Comunicado Técnico, 92).

FRANZON, R.C.; CASTRO, C.M.; RASEIRA, M.C.B. Variabilidade genética em populações de pitangueira oriundas de autopolinização e polinização livre, acessada por AFLP. Revista Brasileira de Fruticultura, Jaboticabal, v.32, n.1, p.240-250, 2010.

GOMES FILHO, A.; OLIVEIRA, J.G.; VIANA, A.P.; SIQUEIRA, A.P.O.; OLIVEIRA, M.G.; PEREIRA, M.G. Marcadores moleculares RAPD e descritores morfológicos na avaliação da diversidade genética de goiabeiras (Psidium guajava L.). Acta Scientiarum Agronomy, Maringá, v.32, p.627-633, 2010.

JUNQUEIRA, K.P.; FALEIRO, F.G. BELLON, G.; JUNQUEIRA, N.T.V.; FONSECA, K.G.; LIMA, C.A.; SANTOS, E.C. Variabilidade genética de acessos de pitaya com diferentes níveis de produção por meio de marcadores RAPD. Revista Brasileira Fruticultura, Jaboticabal, v.32, n.1, p.840-846, 2010.

LACERDA, C.M.B.; KAGEYAMA, P.Y. Estrutura genética de duas populações naturais de Myracrodruon urundeuva M. Allemão na Região Semi-árida, Brasil. Revista Árvore, Viçosa, MG, v.27, p.145-50, 2003. 
MARTINS-CORDER, M.P.; BRITTO FIALHO, L.E.; ZAMBIAZI, D.C.; KONZEN, E.R. Análise da diversidade genética de populações de palmiteiro (Euterpe edulis MARTIUS) através de marcadores isoenzimáticos. Revista Ceres, Viçosa, MG, v.56, p. 200-13, 2009.

MOURA, M. C. O. Distribuição da variabilidade genética em populações naturais de Eremanthus erythropappus (DC.) MacLeish por isoenzimas e RAPD. 2005. Tese (Doutorado em Engenharia Florestal) - Universidade Federal de Lavras, Lavras, 2005.

NEI, M. Analysis of genetic diversity in subdivided populations. Proceedings of National Academy of Sciences, Washington, v.70, p.3321-323, 1973.

NEI, M.; LI, W. Mathematical model for studying genetic variation in terms of restriction endonucleases. Proceedings of the National Academy of Sciences from the USA, Washington, v.76, p.5269-273, 1979.

OLIVEIRA, D.A.; PAULA, F.; PIMENRA, M.A.S.; BRAGA, R.F.; FERREIRA, M.F.; RODRIGUES, L.A. Variabilidade genética de populações de Fava D'anta (Dimorphandra mollis) da Região Norte do Estado de Minas Gerais. Revista Árvore, São Paulo, v.32, p.35563, 2008.

RAJESH, M.K.; JERARD, B.A.; PREETHI, P.; THOMAS,R.J.; KARUN, A. Application of RAPD markers in hybrid verification in coconut. Crop Breeding and Applied Biotechnology, Londrina, v.14, p.36-41, 2014.

RESSEL, K.A., LIMA-RIBEIRO, M.S.; REIS, E.F. Desempenho de progênies de diferentes matrizes de cajuzinho-do-cerrado mediante o armazenamento e o peso das núculas. Ciência Rural, Santa Maria, v.45, p.1782$787,2015$.

ROCHA, M.S.; FIGUEIREDO, R.W.; ARAÚJO, M.A.M.; MOREIRA-ARAÚJO, R.S.R. Caracterização físicoquímica e atividade antioxidante (in vitro) de frutos do cerrado Piauiense. Revista Brasileira de Fruticultura, Jaboticabal, v.35, n.4, p.933-941, 2013.

SALES, E.; NEBAUER, S.G.; MUS, M.; SEGURA, J. Population genetic study in the Balearic endemic plant species Digitalis minor (Scrophulariaceae) using RAPD markes. American Journal of Botany, New York, v.88, p.1759-759, 2001.
SILVA-LUZ, C.L.; PIRANI, J.R. Anacardiaceae. Lista de espécies da flora do Brasil. Rio de Janeiro: Jardim Botânico, 2010. Disponível em: http://floradobrasil.jbrj. gov.br/2010/FB015463. Acesso em: 22 jul. 2016.

TOREZAN, J.M.D.; SOUZA, R.F.; RUAS, P.M.; RUAS, C.F.; CAMARGO, E.H.; VANZELA, A.L.L. Genetic variabilithy of pré and post-fragmentation cohorts of Aspidosperma polyneuron Muell. Arg. (Apocynaceae). Brazilian Archives of Biology and Technology, Curitiba, v.48, p.171-80, 2005.

WADT, H.O. Estrutura genética de populações naturais de pimenta longa (Piper hispidinervum C. DC.) visando seu uso e conservação. 2001. Tese (Doutorado em Genética e melhoramento de Plantas) - Escola Superior de Agricultural Luis de Queiroz, Universidade de São Paulo, Piracicaba, 2001.

WRIGHT. S. Evolution and genetics of populations: variability within and among natural populations. Chicago: University of Chicago Press, 1978.

YANAKA, F.Y.; DALL'AGNOL, M.; SCHIFINOWITTMANN, M.T.; DIAS, P.M.B.; GOMES, K.E. Variabilidade genética em populações naturais de Bromus auleticus Tris. Ex Ness (Poaceae) com base em isoenzimas e marcadores RAPD. Revista Brasileira de Zootecnia, Viçosa, MG, v.34, p.1897-904, 2005.

YEH, F. Populations genetics. In: YOUNG, A.; BOSKIER, D. BOYLE, T. (ed.). Forest conservation genetics: principles and practice. Melbourne: Csiro Publishing, 2000. 352p.

YOUNG, A.; BOSKIER, D. BOYLE, T. Forest conservation genetics. Melbourne: CSIRO, 2000.352p.

ZIMBACKA, L.; MORI, E.S.; KAGEYAMA, P.Y.; VEIGA, R.F.A.; MELLO JUNIOR, J.R.S. Estrutura genética de populações de Trichilia pallida Swartz (Meliaceae) por marcadores RAPD Genetic structure of Trichilia pallida Swartz (Meliaceae) populations by RAPD markers. Scientia Forestalis, Piracicaba, v.65, p.114-119, 2004. 